\title{
Maxillary incisors mesiodistal angulation changes in patients with orthodontically treated anterior superior diastemas
}

Juliana Fernandes de Morais ${ }^{1}$, Marcos Roberto de Freitas², Karina Maria Salvatore de Freitas ${ }^{3}$, Guilherme Janson ${ }^{4}$, Nuria Cabral Castello Branco ${ }^{5}$, Marcelo Zanda ${ }^{6}$

Objective: The aims of this study were to describe the patterns of maxillary incisor angulation in patients with upper interincisive diastemas, to evaluate angulation changes with treatment and posttreatment period, and to assess whether there are association between incisor angulation and interincisive diastema relapse.

Methods: The sample comprised 30 Class I or Class II patients with at least one pretreatment anterior diastema of $0.77 \mathrm{~mm}$ or greater after eruption of maxillary permanent canines. Data were obtained from panoramic radiographs at pretreatment, posttreatment and at least 2 years post-retention.

Results: Incisors presented a mesial tipping tendency after treatment, but only lateral incisors showed significant changes between pre and posttreatment stages.

Conclusion: Regarding post-retention period, no changes were found. Finally, no relation was found between diastema relapse and maxillary incisor axial angulation.

Keywords: Angulation. Diastema. Stability. Panoramic radiograph. Orthodontics.

\footnotetext{
${ }^{1}$ MSc and PhD in Orthodontics, FOB-USP.

${ }^{2}$ Head Professor of Orthodontics, Head of the Graduate Course in Orthodontics, FOB-USP.

${ }^{3}$ Associate Profesor of Orthodontics, UNINGÁ-Maringá.

${ }^{4}$ Head Professor FOB-USP, Head of the Department of Pedodontics, Orthodontics and Public Health, Head of the Masters Course in Orthodontics, FOB-USP.

${ }^{5} \mathrm{MSc}$ and $\mathrm{PhD}$ student in Orthodontics, FOB-USP.

${ }^{6} \mathrm{MSc}$ and $\mathrm{PhD}$ in Stomatology, FOB-USP.
}

\footnotetext{
How to cite this article: Morais JF, Freitas MR, Freitas KMS, Janson G, Branco NCC, Zanda M. Maxillary incisors mesiodistal angulation changes in patients with orthodontically treated anterior superior diastemas. Dental Press J Orthod. 2012 July-Aug;17(4):65-71.
Submitted: April 29, 2009 - Revised and accepted: October 22, 2009
» Patients displayed in this article previously approved the use of their facial and in- traoral photographs.
" The authors report no commercial, proprietary or financial interest in the products or companies described in this article.
Contact address: Juliana Fernandes de Morais
Alameda Dr. Octávio Pinheiro Brisolla, 9-75 - CEP 17012-901 - Bauru/SP -Brazil
E-mail: julianaf_morais@hotmail.com




\section{Alteração das angulações mesiodistais dos incisivos superiores em pacientes com diastemas anterossuperiores tratados ortodonticamente}

Juliana Fernandes de Morais ${ }^{1}$, Marcos Roberto de Freitas², Karina Maria Salvatore de Freitas ${ }^{3}$, Guilherme Janson ${ }^{4}$, Nuria Cabral Castello Branco ${ }^{5}$, Marcelo Zanda ${ }^{6}$

Objetivo: esse trabalho teve por objetivo descrever o padrão de angulações mesiodistais dos incisivos superiores em pacientes com diastemas nessa área e observar as alterações dessas angulações durante e após o tratamento ortodôntico. Também objetivou analisar se existe associação entre as angulações mesiodistais desses dentes nos estágios inicial, final de tratamento e pós-contenção e a recidiva dos diastemas anterossuperiores.

Métodos: a amostra consistiu de 30 pacientes que foram avaliados antes do tratamento, logo após e passados 7 anos da remoção do aparelho ortodôntico. Os indivíduos apresentavam má oclusão de Classe I ou Classe II e, pelo menos, um diastema interincisivos com largura mínima de 0,77mm antes do tratamento. Além disso, os caninos superiores permanentes apresentavam a metade da coroa na cavidade bucal, no mínimo.

Resultados: as angulações dos incisivos apresentaram tendência à mesialização com o tratamento ortodôntico, sendo que houve diferença significativa apenas para as angulações dos incisivos laterais. No período pós-contenção, as angulações de todos os incisivos permaneceram estáveis. Não foi observada associação entre a recidiva dos diastemas e as angulações dos incisivos superiores.

Conclusão: as angulações mesiodistais dos incisivos de pacientes com diastemas nessa área sofreram poucas modificações com o tratamento, havendo uma maior tendência de mesialização das coroas dos incisivos laterais. Os resultados obtidos com o tratamento permaneceram estáveis. Não houve associação entre a recidiva dos diastemas anterossuperiores e as posições mesiodistais dos dentes analisados.

Palavras-chave: Diastema. Radiografia panorâmica. Incisivo. Ortodontia. Recidiva.

${ }^{1}$ Mestre e Doutoranda em Ortodontia, FOB-USP.

${ }^{2}$ Professor Titular de Ortodontia, FOB-USP. Coordenador do Programa de PósGraduação em Ortodontia, FOB-USP.

${ }^{3}$ Professora Adjunta de Ortodontia, UNINGÁ.

${ }^{4}$ Chefe do Departamento de Odontopediatria, Ortodontia e Odontologia em Saúde Coletiva, FOB-USP. Coordenador do curso de Mestrado, FOB-USP.

${ }^{5}$ Mestre e Doutoranda em Ortodontia, FOB-USP.

${ }^{6}$ Mestre e Doutor em Estomatologia, FOB-USP.
Como citar este artigo: Morais JF, Freitas MR, Freitas KMS, Janson G, Branco NCC, Zanda M. Maxillary incisors mesiodistal angulation changes in patients with orthodontically treated anterior superior diastemas. Dental Press J Orthod. 2012 July-Aug;17(4):65-71.

Enviado em: 29 de abril de 2009 - Revisado e aceito: 22 de outubro de 2009

» Os pacientes que aparecem no presente artigo autorizaram previamente a publicação de suas fotografias faciais e intrabucais.

» Os autores declaram não ter interesses associativos, comerciais, de propriedade ou financeiros, que representem conflito de interesse nos produtos e companhias descritos nesse artigo.

Endereço para correspondência: Juliana Fernandes de Morais Alameda Dr. Octávio Pinheiro Brisolla, 9-75 - CEP 17012-901 - Bauru/SP E-mail: julianaf_morais@hotmail.com 


\section{INTRODUCTION}

Mesiodistal angulation of teeth may influence the harmony of the smile and the posterior occlusion. ${ }^{4}$ Furthermore, orthodontic finishing with parallel roots promotes correct occlusal force distribution and contributes for treatment stability. ${ }^{9}$

Depending on the amount of mesiodistal tipping, the space occupied by a tooth can be altered, modifying the arch length or filling previous spacing. This association is more perceptible in the maxillary anterior segment due to the longer crown shapes compared to the buccal crown shapes.

The ideal root mesiodistal positioning is still dubious in the literature. Some authors defend that finishing with parallel roots reduces the risk of space reopening after space closure mechanics. ${ }^{9,10,20}$ Andrews ${ }^{4}$ determined average values for each tooth angulation based on normal occlusion patients and asserted that those values should be aimed when treating orthodontic patients. On the other hand, it was cited that positioning the maxillary central incisors with more divergent roots improve median diastema closure stability. ${ }^{17}$

It is well-known that during the development of occlusion the maxillary incisors exhibit divergent crowns and generalized spacing. These spaces are normally closed spontaneously and the incisors become more mesially tipped. ${ }^{8}$ However, a prevalence ranging from 1.7 to $38 \%$ of patients remains with anterior spacing during permanent dentition. ${ }^{14,16,23,25,29}$

One of the most common treatment approach of maxillary anterior spacing is closing the spaces by orthodontic movement. ${ }^{2,5,12,13,24}$ Yet there is evidence that orthodontic closure of median diastema is not stable out of retention ${ }^{10,24,26}$ (Fig 1). Among the possible contributing factors for diastema relapse is the incisor root mesiodistal positioning.

Few studies evaluated changes in teeth angulations during and after orthodontic treatment., ${ }^{1,7}$ But changes in incisor angulations specifically in patients with maxillary anterior spacing was still not assessed.

Therefore, the objective of this study was to describe the mesiodistal angulation pattern of the maxillary incisors in patients with anterior spacing and evaluate changes in the incisor angulations during treatment and after retention. Additionally, we aim to analyze whether there is association between incisor angulations at pretreatment, post-treatment and post-retention stages, and maxillary anterior spacing relapse.

\section{OBJECTIVE}

The aim of this study was to describe the mesiodistal angulation pattern of the upper incisors in patients with diastema in this area and observe the alteration of this angulation during the orthodontic treatment and after removing the upper retention. Also, verify whether there is an association between the mesiodistal angulation of these teeth in the initial and final stages of treatment and the post-retention and the anterior superior diastema relapse.

\section{MATERIAL AND METHODS Material}

The subjects evaluated in this study were selected from the files of the Orthodontic Department at the University of São Paulo, which comprised 4334 patients. Inclusion criteria comprised maxillary interincisor diastema equal to or greater than $0.77 \mathrm{~mm}$, after partial eruption of the maxillary canines. Subjects with missing anterior teeth, periodontal disease with bone loss, generalized microdontia, maxillary pathologies, mesiodens, diastema closure by a nonorthodontic method and post-orthodontic restoration of maxillary anterior teeth resulting in increase in mesiodistal width were excluded.

Ninety panoramic radiographs of 30 subjects (13 male and 17 female) taken at pre-treatment $\left(\mathrm{T}_{1}\right)$, post-treatment $\left(\mathrm{T}_{2}\right)$ and post-retention $\left(\mathrm{T}_{3}\right)$ stages

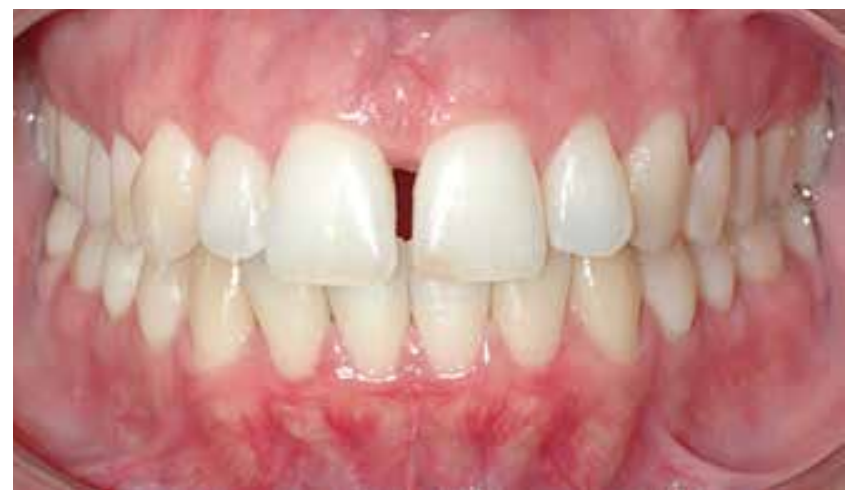

Figure 1 - Example of anterior superior diastema relapse. Photograph obtained 10 years after removing the superior Hawley retainer. 
were selected. All patients were treated nonextraction. Eighteen subjects showed a Class I and 12 of them showed a Class II malocclusion. Maxillary canines were completely erupted in 20 patients. The average initial age was 12.94 years (SD 1.27) and the treatment time was 2.38 years (SD 1.06). The retention time and the period between the appliance removal and the last follow-up appointment were 1.44 (SD 0.48) and 7.05 (SD 3.60) years, respectively.

\section{Methods}

Measurements of spaces between maxillary central and lateral incisors were taken on dental casts taken at $\mathrm{T}_{1}, \mathrm{~T}_{2}$, and $\mathrm{T}_{3}$ with a $0.01 \mathrm{~mm}$ precision digital caliper (Mitutoyo, Japan). Widths were considered to be the smallest distance between adjacent teeth at the gingival level (Fig 2). The sum of the maxillary interincisor widths at post-treatment $\left(\mathrm{T}_{2}\right)$ and post-retention $\left(\mathrm{T}_{3}\right)$ stages were obtained. The space relapse was calculated by subtracting the sum of the spaces at $\mathrm{T}_{3}$ minus the sum of the spaces at $\mathrm{T}_{2}$. According to this result, the sample was divided into two groups stable and unstable. Unstable cases occurred when the result was greater than zero.

Panoramic radiographs of 24 patients were taken with a Rotograph Plus unit (Villa Sistemi Medicali, Italy) which shows a mean linear magnification of $25 \%$. While six patients had their pretreatment and post-treatment panoramic projections taken with as Orthophos CD unit (Siemens Medical Systems, Germany), which presents a mean linear magnification of $27 \%$.

The panoramic radiographs were traced by the same examiner using a $0.5 \mathrm{~mm}$ pencil on a sheet of acetate paper $(14 \times 21 \mathrm{~cm})$ placed over the radiographic film. The inferior outline of the orbits, the inferior outlines of the zygomatic processes of the maxilla and the contours of the maxillary incisors were traced. The horizontal reference lines used were interorbital (IO), passing through the most inferior point of the right and left orbits, and the interzygomatic processes of the maxilla (IZP), passing through the most inferior point of the right and left zygomatic processes of the maxilla. Each incisor long-axis was traced determined by its pulp canal long-axis (Fig 3).

The analyzed variables were: RLI (angle between the long axis of the right lateral maxillary incisor and the IZP line), RCI (angle between the long axis of the right central maxillary incisor and the IZP line), LCI (angle between the long axis of the left central maxillary incisor and the IZP line), and LLI (angle between the long axis of the left lateral maxillary incisor and the IZP line).

In this study, the IZP line was used because only twenty patients presented both orbital inferior contours in the panoramic radiographs of the initial, final and follow-up stages. The angle IO.IZP between the IO and the IZP reference lines was evaluated in
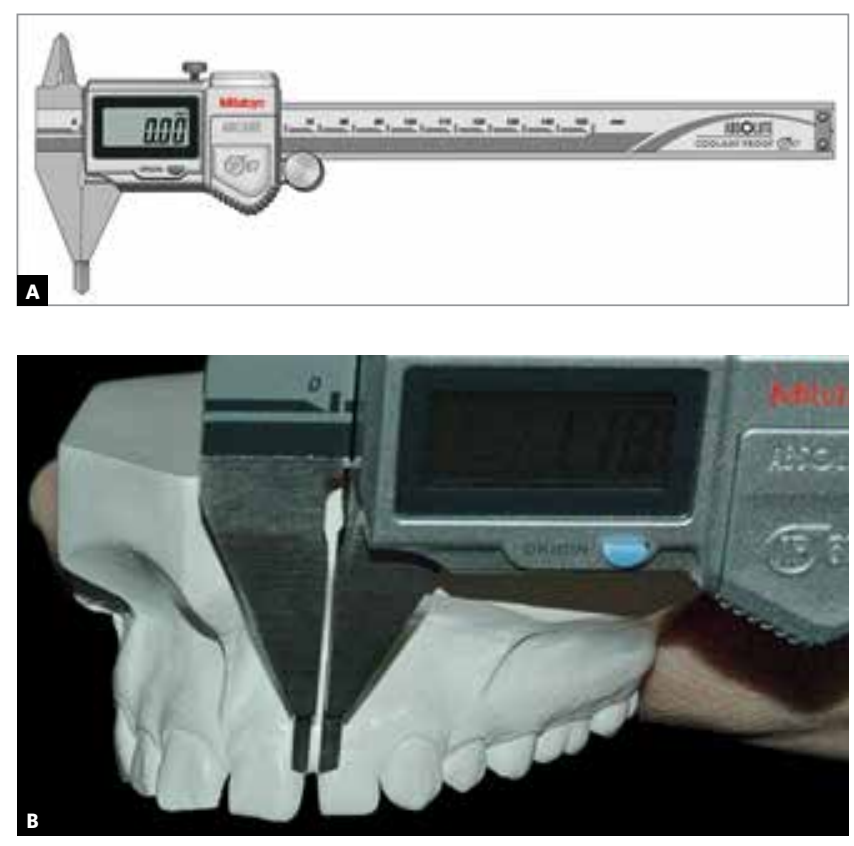

Figure 2 - A) Digital caliper Mitutoyo used to measure interincisor spacing. B) Diastema measurement method.

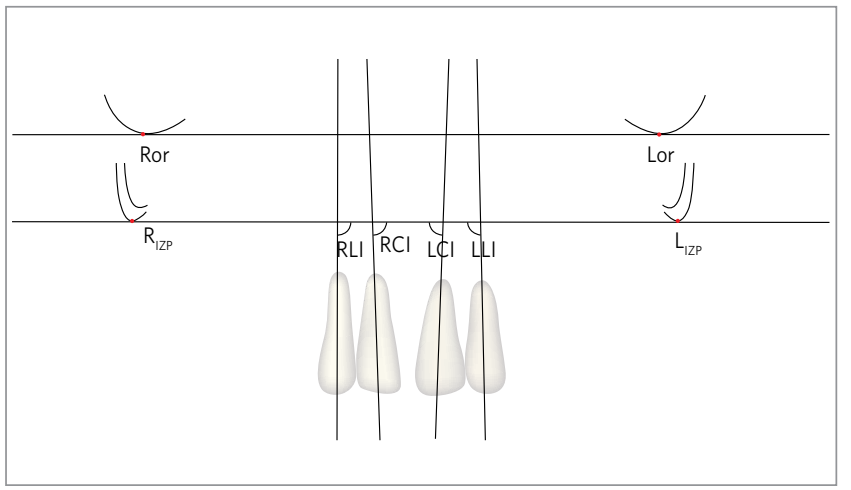

Figure 3 - Schematic design of the radiographic tracings performed showing the orbital contours, zygomatic processes of maxilla, contour of maxillary incisors, as well as the reference lines interorbitary (IO), interzygomatic processes (IZP), and teeth long axes. 
twenty patients where the orbital contours could be traced. When the lines converged at the right side the values were written positive, while when the convergence occurred at the left side the values were written negative.

\section{Statistical analyses}

Thirty panoramic radiographs were retraced and remeasured by the same examiner after a month interval. The casual error was calculated according to Dahlberg's formula. ${ }^{2}$ The systematic errors were analyzed with a $t$ test ${ }^{16}$ at $\mathrm{p}<0.05$.

Mean values and standard deviations of each maxillary incisor angulations were calculated at the initial $\left(\mathrm{T}_{1}\right)$, final $\left(\mathrm{T}_{2}\right)$, and post-retention $\left(\mathrm{T}_{3}\right)$ stages and were compared by repeated measures ANOVA, followed by Tukey post hoc test, in order to evaluate the changes occurred during treatment $\left(\mathrm{T}_{1}\right.$ and $\left.\mathrm{T}_{2}\right)$, to analyze the stability of treatment outcomes $\left(\mathrm{T}_{2}\right.$ and $\mathrm{T}_{3}$ ) as well as to verify if the angulations after retention and before treatment were similar.

Since the patients evaluated are in growing phase, repeated measures ANOVA, followed by Tukey tests, were used to assess the changes in the parallelism between IO and IZP lines.

Student's $t$ tests were used to compare mesiodistal angulations between the stable and unstable groups at $\mathrm{T}_{1}, \mathrm{~T}_{2}$ and $\mathrm{T}_{3}$.

\section{RESULTS}

\section{Method precision}

The casual error was found to be small and acceptable for all measurements, while the systematic error was not statistically significant for any measurement (Tab 1).

The angle between the IZP and IO lines with a maximum divergence of $2^{\circ}$ at all stages (Tab 2) demonstrates an acceptable parallelism between these lines.

Incisor angulations showed a tendency for mesial inclination during orthodontic treatment but the changes were significant only for lateral incisor angulations (Tab 3). On the other hand, all incisor angulations remained stable during post-retention period.

No differences were found between stable and unstable groups (Tab 4). This suggests that there was no association between space relapse and mesiodistal angulations.

\section{ANOVA and Tukey test results}

Generally, the angulation of the incisors presented a tedency to mesialization with orthodontic treatment, and there was a significant difference only for the lateral incisors angulation (Tab 3). In the postretention stage, the angulation of all incisors remained stable.

\section{Angulation comparison between stable and non-stable groups}

No significant difference was verified between groups (Tab 4). This fact suggests that there was no relation between diastemas relapse and mesiodistal angulations.

\section{DISCUSSION}

Since the development and improvement of the panoramic radiograph technique by Paatero, ${ }^{18,19}$ it has been recognized as an essential diagnosis method because it is possible to show on the same film the whole dentition, alveolar bone, temporomandibular joint and adjacent structures. Additionally, panoramic radiographs help the evaluation of mesiodistal teeth angulations before and after treatment $\mathrm{t}^{1,11,15,30}$ and root parallelism near extraction areas. ${ }^{11,15}$

Table 1 - Method error for repeated measurements.

\begin{tabular}{|c|c|c|c|c|c|c|c|}
\hline & \multicolumn{2}{|c|}{ 1st measurement } & \multicolumn{2}{|c|}{ 2nd measurement } & \multirow{2}{*}{$\begin{array}{c}\text { Systematic error } \\
\text { p }\end{array}$} & \multirow{2}{*}{$\begin{array}{l}\text { Casual error } \\
\text { Dahlberg }\end{array}$} & \multirow{2}{*}{$\mathbf{n}$} \\
\hline & Mean & SD & Mean & SD & & & \\
\hline LLI & 96.89 & 4.95 & 95.59 & 4.28 & 0.597 & 1.45 & 30 \\
\hline $\mathrm{LCl}$ & 89.72 & 3.29 & 89.88 & 3.55 & 0.589 & 1.38 & 30 \\
\hline $\mathrm{RCl}$ & 87.96 & 3.89 & 87.71 & 2.39 & 0.781 & 1.29 & 30 \\
\hline RLI & 96.43 & 5.19 & 95.92 & 5.01 & 0.498 & 1.37 & 30 \\
\hline IO.IZP & 0.07 & 0.90 & 0.07 & 0.95 & 0.988 & 0.17 & 20 \\
\hline
\end{tabular}


Table 2 - Descriptive statistics and repeated measures analysis of variance comparing the angle between interorbitary and inter-zigomatic processes of maxilla in initial, final, and postretention stages.

\begin{tabular}{|c|c|c|c|c|c|c|c|c|c|c|c|}
\hline & \multicolumn{4}{|c|}{$\begin{array}{c}\text { Total (3 stages) } \\
\qquad \begin{array}{c}\mathrm{N}=20 \\
\end{array}\end{array}$} & \multicolumn{2}{|c|}{$\begin{array}{c}\text { Initial }\left(T_{1}\right) \\
N=20\end{array}$} & \multicolumn{2}{|c|}{$\begin{array}{l}\text { Final }\left(T_{2}\right) \\
n=20\end{array}$} & \multicolumn{2}{|c|}{$\begin{array}{l}\text { Post-retention } \\
\left(\mathrm{T}_{3}\right) \mathrm{n}=20\end{array}$} & \multirow[t]{2}{*}{$\begin{array}{c}\text { ANOVA } \\
\mathbf{p}\end{array}$} \\
\hline & Mean & SD & Min & $\operatorname{Max}$ & Mean & SD & Mean & SD & Mean & SD & \\
\hline IO.IZP & 0.07 & 0.90 & -2.0 & 2.0 & 0.08 & 0.95 & 0.03 & 0.64 & 0.13 & 1.10 & 0.94 \\
\hline
\end{tabular}

Table 3 - Results of repeated measures analysis of variance, followed by Tukey tests comparing mesiodistal angulations of each incisor at all stages $T_{1}$ $\mathrm{T}_{2}$ and $\mathrm{T}_{3}$

\begin{tabular}{|c|c|c|c|c|c|c|c|c|}
\hline & \multicolumn{2}{|c|}{ LLI } & \multicolumn{2}{|c|}{$\mathbf{L C I}$} & \multicolumn{2}{|c|}{$\mathbf{R C I}$} & \multicolumn{2}{|c|}{ RLI } \\
\hline & Mean & SD & Mean & SD & Mean & SD & Mean & SD \\
\hline Initial $\left(T_{1}\right)$ & $98.37^{A}$ & 4.47 & 90.70 & 3.26 & 89.33 & 3.90 & $97.12^{\mathrm{A}}$ & 5.05 \\
\hline Final $\left(T_{2}\right)$ & $96.55^{\mathrm{AB}}$ & 5.36 & 89.32 & 3.36 & 87.68 & 3.76 & $94.25^{B}$ & 5.30 \\
\hline Post-retention $\left(\mathrm{T}_{3}\right)$ & $95.08^{B}$ & 4.28 & 89.18 & 3.31 & 87.67 & 3.40 & $93.90^{B}$ & 3.16 \\
\hline$p($ ANOVA) & \multicolumn{2}{|c|}{$0.031^{\star}$} & \multicolumn{2}{|c|}{0.151} & \multicolumn{2}{|c|}{0.139} & \multicolumn{2}{|c|}{$0.015^{\star}$} \\
\hline
\end{tabular}

${ }^{*}$ statistically significant for $\mathrm{p}<0,05$.

It is known that panoramic radiographs as well as any extraoral radiograph exhibit magnification of the real image..$^{3,6}$ But in panoramic radiographs the amount of magnification varies in different sites of the film due to the method of image acquisition by moving the X-ray tube. The linear measurements, especially horizontal ones, demonstrate significant magnification and are not reliable. In the other hand, angular measurements exhibit smaller distortions $\mathbf{s}^{6,11,15,22}$, specially on the anterior region, ${ }^{3,21}$ confirming that panoramic radiographs can be a reliable method to evaluate angular measurements on maxillary anterior teeth.

It is traditionally advocated that appropriate root parallelism improves treatment stability, ${ }^{9,10,20}$ especially in the areas of space closure after extractions. ${ }^{9,20}$ In cases with anterior spacing, the incisor mesiodistal positions has been mentioned to influence stability, ${ }^{10,17}$ even though there is no study evaluating the mesiodistal angulations of maxillary anterior teeth in cases with interincisor diastema.

Some studies ${ }^{1,7,28,30}$ have evaluated teeth angulations with panoramic radiographs, using the interorbital line (IO) as reference. Nevertheless, in our study, ten patients did not show both orbital inferior contours in the panoramic radiographs of the initial, final and follow-up stages. Therefore, the zygomatic processes of the maxilla were traced so that interzygomatic processes of the maxilla (IZP) line,
Table 4 - Results of Student $\mathrm{t}$ tests comparing the incisor angulations in each stage $T_{1}, T_{2}$, and $T_{3}$ between the groups stable and unstable.

\begin{tabular}{lccccc} 
& \multicolumn{2}{c}{ Stable $(\mathbf{n = 1 4})$} & \multicolumn{2}{c}{ Unstable $(\mathbf{n = 1 6})$} & p \\
\cline { 2 - 4 } & Mean & SD & Mean & SD & \\
\hline LLI-T1 & 98.36 & 5.02 & 98.38 & 4.11 & 0.992 \\
LCI-T1 & 91.89 & 3.11 & 89.66 & 3.10 & 0.059 \\
RCI-T1 & 89.75 & 3.37 & 88.97 & 4.39 & 0.593 \\
RLI-T1 & 96.21 & 5.79 & 97.91 & 4.33 & 0.369 \\
LLI-T2 & 96.36 & 6.96 & 96.72 & 3.69 & 0.858 \\
LCI-T2 & 89.54 & 4.30 & 89.13 & 2.38 & 0.744 \\
RCI-T2 & 87.29 & 4.12 & 88.03 & 3.50 & 0.596 \\
RLI-T2 & 93.21 & 6.53 & 95.16 & 3.95 & 0.326 \\
LLI-T3 & 95.25 & 3.91 & 94.94 & 4.70 & 0.846 \\
LCI-T3 & 88.86 & 3.41 & 89.47 & 3.30 & 0.622 \\
RCI-T3 & 87.54 & 4.02 & 87.78 & 2.88 & 0.847 \\
RLI-T3 & 93.68 & 3.61 & 94.09 & 2.80 & 0.726 \\
\hline
\end{tabular}

similar to IO line, was used. The results showed an acceptable parallelism (Tab 2) and a maximum divergence of $2^{\circ}$ between these lines. This demonstrates that the IZP line can be as reliable as the interorbital line and the values obtained in this study can be compared to those proposed by $\mathrm{Ursi}^{30} \mathrm{ob}-$ tained from patients with normal occlusion.

According to repeated measures analysis of variance (Tab 3), the changes in the maxillary central incisors angulations were not significant during $\left(\mathrm{T}_{1}-\mathrm{T}_{2}\right)$ 
and after treatment $\left(\mathrm{T}_{2}-\mathrm{T}_{3}\right)$, except for the lateral incisor angulations, which showed significant changes in both periods. There was a tendency for crown mesialization, which may be explained by the mechanics used, which included an association of preadjusted appliances with elastomeric chains. The high forces produced might cause great crown mesialization if used on light wires (Fig 4).

The mesiodistal angulations achieved with treatment remained stable (Tab 3). These findings shows that finishing with ideal angulations should be a relevant treatment objective, since the patient's smile will show the positions obtained, even after a long period out of retention.

Diastema relapse is quite often on maxillary anterior area. ${ }^{10,24,26,27}$ Some authors reported that space reopening might be associated with an inappropriate root positioning at the end of treatment. However our results showed no difference between stable and unstable groups in central and lateral incisor angulations when compared in each initial, final, post-retention stages. In conclusion, this demonstrates that no association between space reopening and mesiodistal angulations was found.

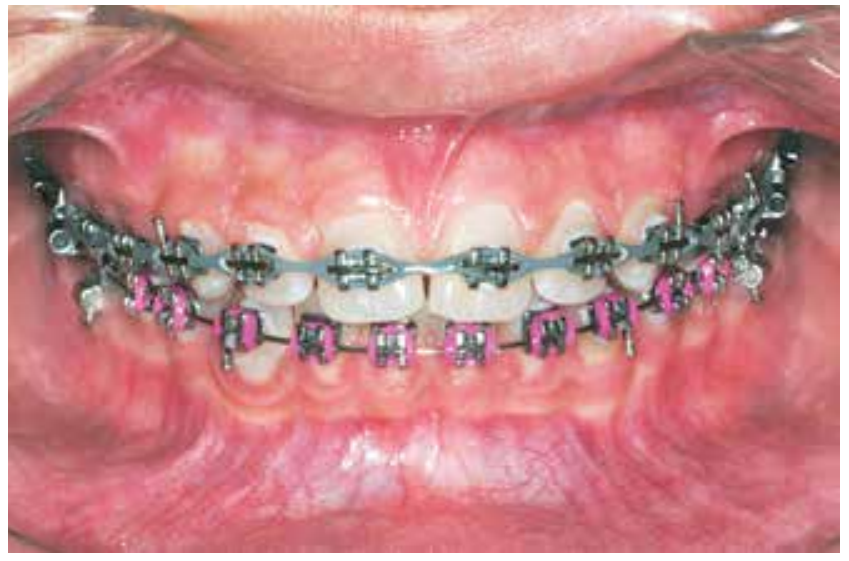

Figure 4 - Effect of crown mesialization induced by elastomeric chain.

\section{CONCLUSIONS}

Based on the method and the results we conclude:

1) Incisor mesiodistal angulations in patients with anterior spacing showed slight changes during treatment with greater crown mesialization on the lateral incisors, which remained stable posttreatment.

2) There was no association between anterior spacing relapse and mesiodistal angulations of the maxillary incisors. 


\section{REFERENCES}

1. Almeida-Pedrin RR, Pinzan A, Almeida RR, Ursi W, de Almeida MR. Panoramic evaluation of mesiodistal axial inclinations of maxillary anterior teeth in orthodontically treated subjects. Am J Orthod Dentofacial Orthop. 2006 Jul;130(1):56-60; discussion 60-1.

2. Almeida RR, Garib DG, Almeida-Pedrin RR, Almeida MR, Pinzan A, Junqueira $\mathrm{MHZ}$. Diastema interincisivos centrais superiores: quando e como intervir? $\mathrm{R}$ Dental Press Ortodon Ortop Facial. 2004 Maio-Jun;9(3):137-56.

3. Almeida SM, Bóscolo FNE, Montebello Filho A. Estudo das distorções da imagem radiográfica produzida em aparelhos panorâmicos que se utilizam dos princípios ortopantomográficos e elipsopantomográficos. Rev Odont USP. 1995 Abr-Jun;9(2):91-9.

4. Andrews LF. The six keys to normal occlusion. Am J Orthod. 1972 Sep;62(3):296- 309.

5. Bishara SE. Management of diastemas in orthodontics. Am J Orthod. 1972 Jan;61(1):55-63.

6. Blackman S. Mass dental radiography. Radiography. 1956 Feb;22(254):21-5.

7. Brandão AG. Estudo ortopantomográfico longitudinal das inclinações axiais mesiodistais em pacientes tratados ortodonticamente com extrações dos quatro primeiros pré-molares [Dissertação]. Bauru (SP): Universidade de São Paulo, Faculdade de Odontologia de Bauru; 2002.

8. Cuoghi OA, Bertoz FA, de Mendonça MR, Santos EC, Li AT. Labiolingual and mesiodistal positioning of maxillary permanent incisors during the eruption process. J Clin Pediatr Dent. 2000 Fall;25(1):13-21.

9. Edwards JG. The prevention of relapse in extraction cases. Am J Orthod. 1971 Aug;60(2):128-44.

10. Edwards JG. The diastema, the frenum, the frenectomy: a clinical study. Am J Orthod. 1977 May; 71(5):489-508

11. Frykholm A, Malmgren O, Sämfors KA, Welander U. Angular measurements in orthopantomography. Dentomaxillofac Radiol. 1977;6(2):77-81.

12. Gardiner JH. Midline spaces. Dent Pract Dent Rec. 1967 Apr;17(8):287-97.

13. Janson GRP, Silva, CCA, Henriques JFC, Freitas MR, Martins DR. Fechamento ortodôntico de diastema entre os incisivos centrais superiores durante a dentadura mista: relato de um caso clínico. Rev Dental Press Ortodon Ortop Facial. 1998 Jul-Ago;3(4):72-8.

14. Lavelle CL. Crowding and spacing within the human dental arch of different racial groups. Arch Oral Biol. 1970 Nov;15(11):1101-3.
15. McKee IW, Williamson PC, Lam EW, Heo G, Glover KE, Major PW. The accuracy of 4 panoramic units in the projection of mesiodistal tooth angulations. Am J Orthod Dentofacial Orthop. 2002 Feb;121(2):166-75; quiz 192.

16. McVay TJ, Latta GH Jr. Incidence of the maxillary midline diastema in adults. J Prosthet Dent. 1984 Dec;52(6):809-11

17. Mulligan TF. Diastema closure and long-term stability. J Clin Orthod. 2003 Oct:37(10):560-74.

18. Paatero YV. A new tomographical method for radiographing curved outer surfaces. Acta Radiol. 1949 Sep 30;32(2-3):177-84, illust.

19. Paatero YV. Pantomography and orthopantomography. Oral Surg Oral Med Oral Pathol. 1961 Aug;14:947-53.

20. Parker GR. Transseptal fibers and relapse following bodily retraction of teeth: a histologic study. Am J Orthod. 1972 Apr;61(4):331-44.

21. Peck JL, Sameshima GT, Miller A, Worth P, Hatcher DC. Mesiodistal root angulation using panoramic and cone beam CT. Angle Orthod. 2007 Mar;77(2):206-13.

22. Philipp RG, Hurst RV. The cant of the occlusal plane and distortion in the panoramic radiograph. Angle Orthod. 1978 Oct;48(4):317-23.

23. Richardson ER, Malhotra SK, Henry M, Little RG, Coleman HT. Biracial study of the maxillary midline diastema. Angle Orthod. 1973 Oct;43(4):438-43.

24. Shashua D, Artun J. Relapse after orthodontic correction of maxillary median diastema: a follow-up evaluation of consecutive cases. Angle Orthod. 1999 Jun;69(3):257-63.

25. Steigman S, Gershkovitz E, Harari D. Characteristics and stability of spaced dentition. Angle Orthod. 1985 Oct;55(4):321-8.

26. Sullivan TC, Turpin DL, Artun J. A postretention study of patients presenting with a maxillary median diastema. Angle Orthod. 1996;66(2):131-8.

27. Surbeck BT, Artun J, Hawkins NR, Leroux B. Associations between initial, posttreatment, and postretention alignment of maxillary anterior teeth. Am J Orthod Dentofacial Orthop. 1998 Feb;113(2):186-95.

28. Tavano O, Ursi WJSE, Almeida RR. Determinação das linhas de referência para medições angulares em radiografias ortopantomográficas. Odontol Mod. 1989;16(9):22-5.

29. Taylor JE. Clinical observations relating to the normal and abnormal frenum labii superians. Am J Orthod and Oral Surg. 1939 Jul;25(7):646-60.

30. Ursi WJ, Almeida RR, Tavano O, Henriques JF. Assessment of mesiodistal axial inclination through panoramic radiography. J Clin Orthod. 1990 Mar;24(3):166-73. 